\begin{tabular}{lc}
$\begin{array}{c}\text { Yanbu Journal } \\
\text { of }\end{array}$ & \\
$\begin{array}{l}\text { Engineering } \\
\text { and Science }\end{array}$ & Vol. 8, April $2014(1435 \mathrm{H})$ \\
\hline \hline ISSN: $1658-5321$ & www.yjes.org.sa
\end{tabular}

\title{
DESIGN AND IMPLEMENTATION OF A RECTANGULAR UWB SLOT ANTENNA SINGLE-BAND NOTCHED AT $5.8 \mathrm{GHz}$
}

\author{
Azzeddine Djaiz ${ }^{1}$, Tarief Elshafiey ${ }^{1}$, Mourad Nedil ${ }^{2}$, Mohamed A. Habib $^{3}$, and Tayeb A. Denidni ${ }^{4}$
}

\author{
1 Yanbu industrial college, Yanbu, Saudi Arabia \\ e-mail:adjaiz@yic.edu.sa \\ 2 LRTCS-UQAT, Vald'Or, Quebec, Canada \\ 3 Yanbu university college, Yanbu, Saudi Arabia \\ 4 University of Quebec (INRS-EMT), Montreal, Quebec, Canada
}

\begin{abstract}
In this paper, a new ultra wideband slot antenna with single notch at $5.8 \mathrm{GHz}$ is presented. This microstrip-fed UWB antenna is composed of a rectangular slot with a rectangular patch-fed coupling effect. This configuration allows optimizing the size, the performance and the characteristics. The proposed UWB-notched antenna meets the FCC bandwidth authorization. The antenna is successfully designed, implemented and measured. Good results in terms of band rejection performance and radiation stability are obtained. The voltage standing wave ratio (VSWR) is less than 2.0 along the FCC bandwidth $3.1-10.6 \mathrm{GHz}$ which provides a fractional bandwidth of more than $115 \%$. Important conclusions on the effect of design parameters on the antenna performance and design optimization are reported.
\end{abstract}

Keywords: Planar antenna, Rectangular slot antenna, Frequency notch, Ultra wideband.

\section{INTRODUCTION}

In the last few years, many significant developments and high attention are being given to ultra wideband (UWB) communication systems since the Federal Communications Commission (FCC) allocated $3.1-10.6 \mathrm{GHz}$ of the frequency spectrum for wireless communication applications [1]. The attractive nature of UWB systems coupled with the rapid growth in wireless communication systems has not only made UWB an outstanding candidate to replace the conventional and popular wireless technologies in use today like Bluetooth and wireless LANs, but also has offered important advantages not achievable by narrowband system as well. This growth leads to a great demand in designing wideband microwave components, such as antennas, couplers, phase shifters and filters. Several antenna configurations including planar monopoles and dipoles have been studied and proposed for ultra broadband applications; however the use of the narrowband systems such as WiMAX band and High Performance Local Area Network (HiPerLAN) band at $3.5 \mathrm{GHz}$ and $5.8 \mathrm{GHz}$ band respectively interferes with ultra wideband systems. To avoid the interference between the two systems, a bandrejection filter is necessary in UWB RF frontends. However, the use of the filter will increase the complexity of the system. These will provide insertion-loss problem, and pattern radiation stability, and the size will be increased. Accordingly, and in order to resolve this problem, some works to notch the 
HiPerLAN (WLAN) and (or) WiMAX bands have been reported and widely discussed [2][14]. For example, Meharanpour et al proposed monopole antenna with dual bandnotch function [7]. The antenna consists of a square patch with a pair of L-shaped slits and an E-shaped slot and a ground plane with a $\mathrm{V}$-shaped strip. The antenna bandwidth is from 2.89 to $17.83 \mathrm{GHz}$. They can switch to single notch by removing the E-shaped slot. The antenna size is small with total area of 10x16 mm2. Planar antennas are suitable solutions to achieve low-cost and reliable radiating device for UWB systems. To overcome these problems, several works have been achieved in this area. A common approach is to use UWB monopole antenna with different shapes [3]. Other techniques with notch function have also been investigated such as, the insertion of the split ring slot resonator, the U-shaped slot resonant structure, or stubs [4-5]. Lee et al have proposed to perturb impedance matching and create an open circuit at the undesired band [15]. However, these techniques can eliminate only one band, or cannot provide a sufficient rejection bandwidth to be used in practical applications. Some other UWB antenna designs use filters to suppress undesirable bands, but the uses of filters increase the complexity of the UWB systems, and consequently their cost [16].

Most of the presented antenna designs are mainly introducing different notch techniques to the radiating elements with complex shapes. The stability of the radiation pattern is questionable for most of the antennas that engrave the radiation patch. In addition, some of the designs introduced bandwidths greater than that authorized by FCC which is not advantageous to go beyond $10.6 \mathrm{GHz}$ since it doesn't have significant practical applications.
In this work, a microstrip-fed planar UWB antenna with single band-notched function at $5.8 \mathrm{GHz}$ is proposed. The operation is achieved by inserting a C-shaped slot in the rectangular patch part connected to microstrip-fed line. The length of the Cshaped slots is approximately half-wavelength of the desired notched frequencies. This work is different than our previously published work for dual band antenna notched at 3.5/5.8 GHz [17]. In our previously published work [17] was based on only simulation results whereas the current work is for single-band antenna but simulation, experimental verification, comparison and discussions are totally presented.

\section{ANTENNA DESIGN}

In order to understand the design parameters of the proposed UWB-notched antenna, it was interesting to design an UWB antenna without notch. Fig. 1 shows the geometry of this antenna. In this configuration, a rectangular slot is fed with a microstrip rectangular patch.

This patch allows not only to feed the slot by coupling effect, but also to match the slot to the $50-\Omega$ microstrip line that is used in the feeding network.

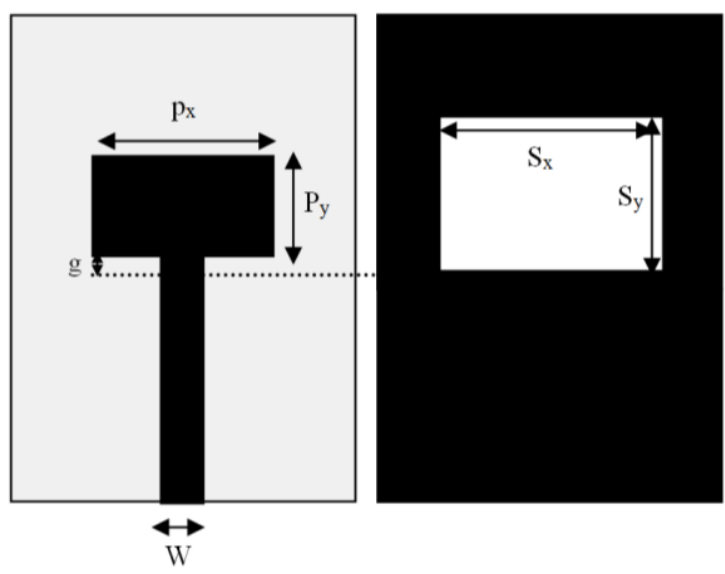

Fig. 1. Layout of the UWB antenna, back (left) and front (right) views 
The antenna is printed on Rogers- 5880 substrate with relative permittivity of 2.2 and thickness of $1.575 \mathrm{~mm}$. On this substrate, a rectangular slot is printed in one side, and on the other one, a rectangular patch is etched. This patch is fed through a microstrip line having a width of $2.8 \mathrm{~mm}$ to ensure matching with $50-\Omega$ characteristic impedance. Fullwave simulations were carried out using HPADS software [18]. Several parameters were investigated and the proposed antenna has been optimized and designed. The parameters of the antenna excited by the rectangular microstrip line section are illustrated in Table 1 and the following conclusions were obtained. The VSWR simulation parameter for the proposed antenna is shown in Fig. 2. From this curve, it can be noted that the antenna meets the FCC bandwidth authorization. The VSWR is less than 2 along the operating bandwidth $3 \mathrm{GHz}$ to $10.5 \mathrm{GHz}$. The frequency band-notch characteristic is obtained around $5.8 \mathrm{GHz}$ by inserting a Cshaped slot in the rectangular part patch connected to microstrip-fed. As expected, this technique leads to produce a mismatching and high attenuation in the bandwidth near the notch frequency can be obtained.

The interference with other narrowband system such as the HiperLAN (WLAN) band can be considerably reduced.

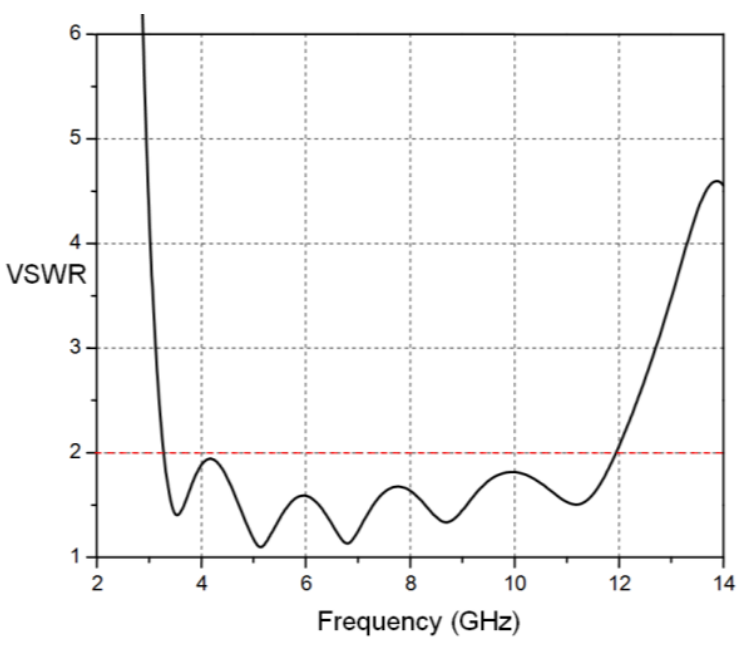

Fig. 2. Simulated of the VSWR of the UWB antenna
Figure 3 shows the layout of the proposed single band-notched UWB antenna. It's designed using Rogers-5880 substrate with relative permittivity of 2.2 and thickness of $1.575 \mathrm{~mm}$ The length $L$ of the C-shaped slot is approximately half-wavelength at the desired notched frequency.
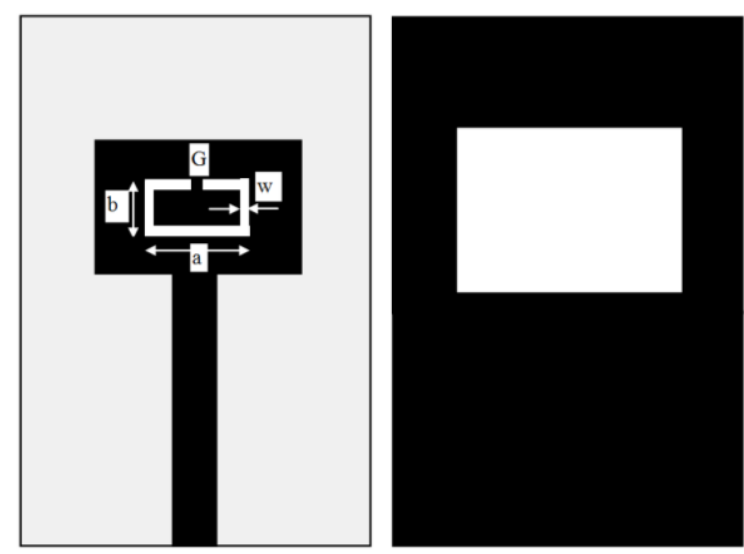

Fig. 3. Geometry of the single-notched Antenna, Front \& Back view

Using Momentum-ADS the dimensions of the $\mathrm{C}$ shaped slot are illustrated in the Table 2 , where a, b, G, and w are the length, the width, the gap, and the slot-width of the $\mathrm{C}$ shaped slot respectively. The notch frequency can be expressed as follow:

$f_{\text {notch }}=\frac{C}{2 L \sqrt{\varepsilon_{r}}}$

Where $\mathrm{C}$ is the velocity of the light.

TABLE 1: THE PARAMETERS OF THE PROPOSED ANTENNA

\begin{tabular}{|l|l|l|l|l|l|}
\hline W & $\mathrm{S}_{\mathrm{x}}$ & $\mathrm{S}_{\mathrm{y}}$ & $\mathrm{P}_{\mathrm{x}}$ & $\mathrm{P}_{\mathrm{y}}$ & $\mathrm{g}$ \\
\hline 3.9 & 27.4 & 19.0 & 12.0 & 5.6 & 1.9 \\
\hline
\end{tabular}

These parameters listed in Table 1 are illustrated in Fig. 1. Where: $S_{x}$ and $S_{y}$ are the dimensions of the rectangular slot, $\mathrm{P}_{\mathrm{x}}, \mathrm{P}_{\mathrm{y}}$ are the dimensions of the rectangular patch, $\mathrm{W}$ is the width of the microstrip feed line and $g$ is the offset.

TABLE 2: THE DIMENSIONS OF THE C SHAPED SLOT

\begin{tabular}{|c|c|c|c|}
\hline $\mathrm{a}$ & $\mathrm{b}$ & $\mathrm{G}$ & $\mathrm{W}$ \\
\hline 8.04 & 4.2 & 2.15 & 0.3 \\
\hline
\end{tabular}


All dimensions in Tables 1 and 2 are in millimeters. The goal is to reach a structure that satisfies the voltage standing wave ratio (VSWR) less than 2.0 along the FCC bandwidth $3.1-10.6 \mathrm{GHz}$. To achieve this goal, a series of several optimization simulation using Momentum-ADS has been implemented and resulted the parameters of the design which are demonstrated in Tables 1 and 2. To do so, many challenges are faced to satisfy the above mentioned conditions. A parametric study of the design parameters (Thickness of the dielectric substrate, dielectric constant and size of the ground plane) are performed and their effects on the VSWR are checked. It is clearly noted that these parameters affect considerably the antenna bandwidth. Moreover, to decrease the return loss particularly at the central frequency, the feeding point is moved until an optimum return loss is obtained.

\section{EXPERIMENTAL RESULTS}

To verify the antenna synthesis method, an experimental UWB- antenna is designed and fabricated on Rogers-5880 substrate with relative permittivity of 2.2 and thickness of $1.575 \mathrm{~mm}$. The dimensions of the proposed UWB- notched antenna were optimized by using a full-wave electromagnetic simulator, ADS-momentum [17].

Fig. 4 shows the photograph of the fabricated UWB-notched antenna prototype.
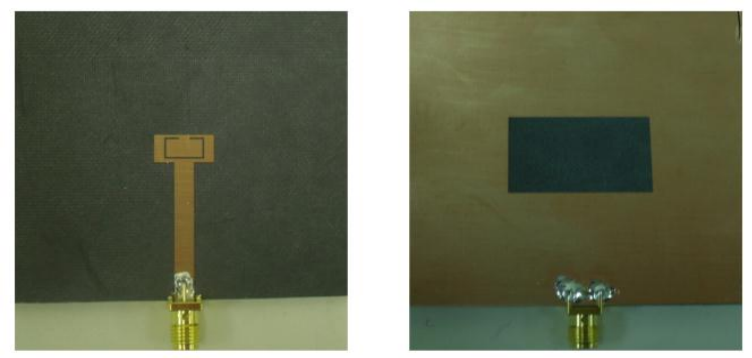

Fig. 4. Photograph of the fabricated prototype single-notched antenna.
To examine the performance of the proposed antenna, experimental measurements for the VSWR are carried out using HP8722 Network analyzer. Also, an anechoic chamber is used to measure the radiation patterns at different frequencies, 3.5, 4.5 and 9 GHZ. Measured and simulated results are presented and compared. Fig. 5 shows simulated and measured VSWR. It can be seen that the VSWR value is less than 2.0 except in the undesirable frequency-band 5.5-5.9 GHz.

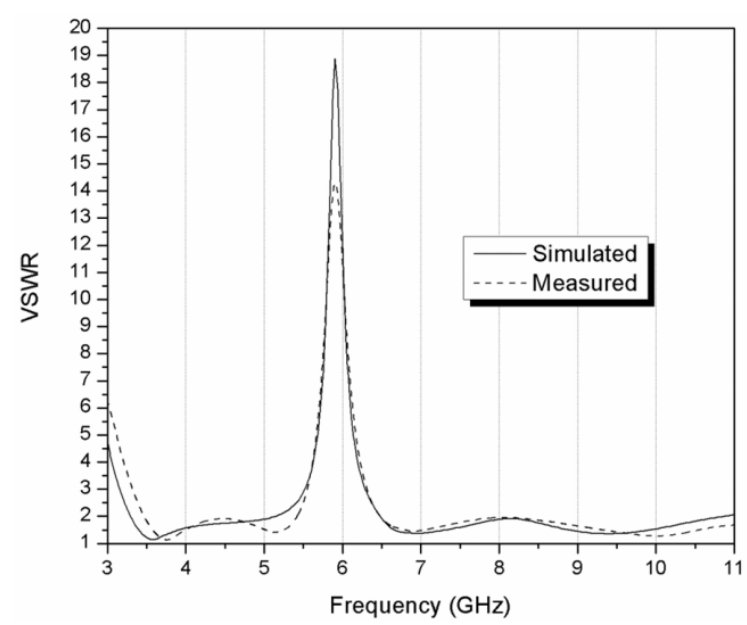

Fig. 5. Simulated and measured VSWR of the single-notched antenna.

The previous results display a good agreement. Fig. 6 shows the simulated and measured radiation patterns for the single notch UWB antenna in both $\mathrm{E}$ - and $\mathrm{H}$ - planes at three different frequencies $(3.5,4.5$ and $9 \mathrm{GHz}$ ). As the figure reveals, the proposed antennas have almost omnidirectional characteristics patterns. Reasonable agreement is also obtained between the measured result and the simulated one, which validates the design approach. It can be noted that this antenna offer a uniform patterns which is desirable to cover the UWB frequencies up to $11 \mathrm{GHz}$. Fig. 7 illustrates the antenna gain with a drop around the rejected-band of $5.8 \mathrm{GHz}$. 

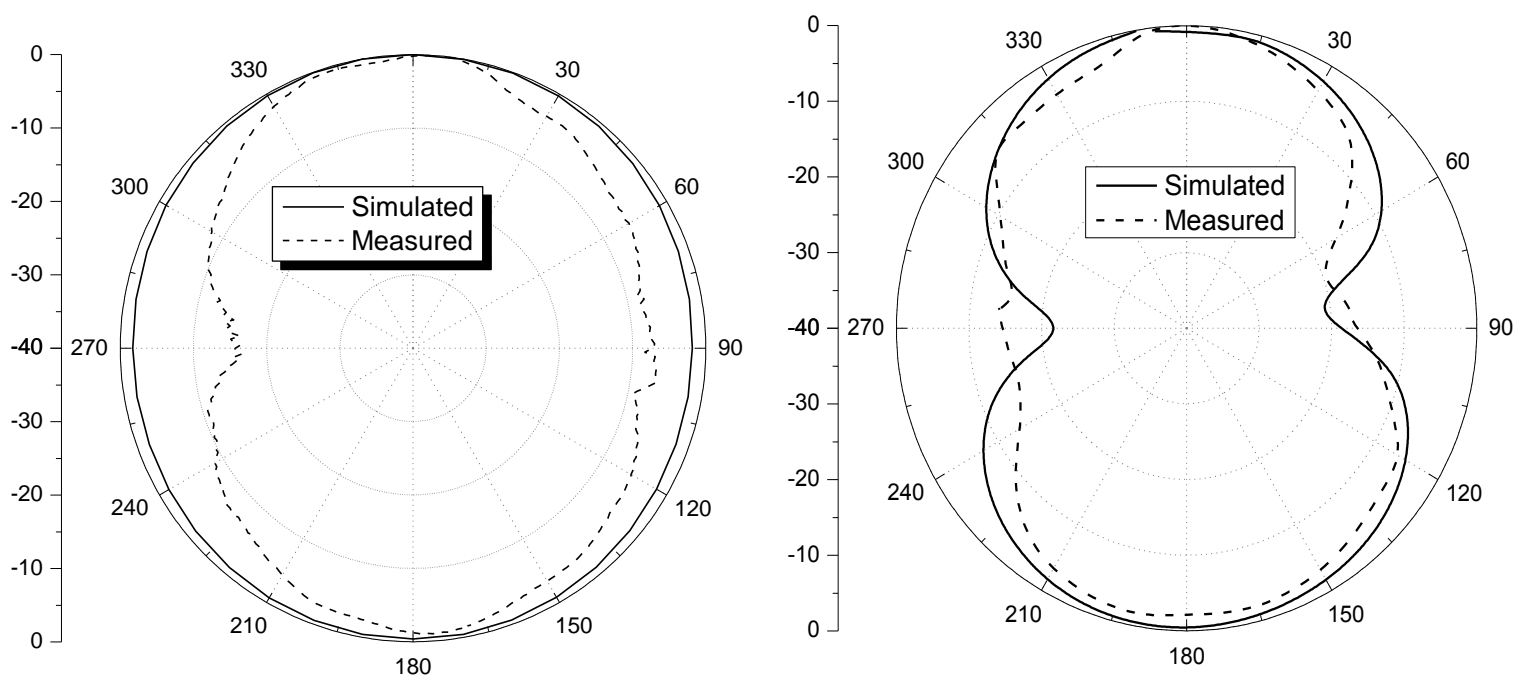

(a)
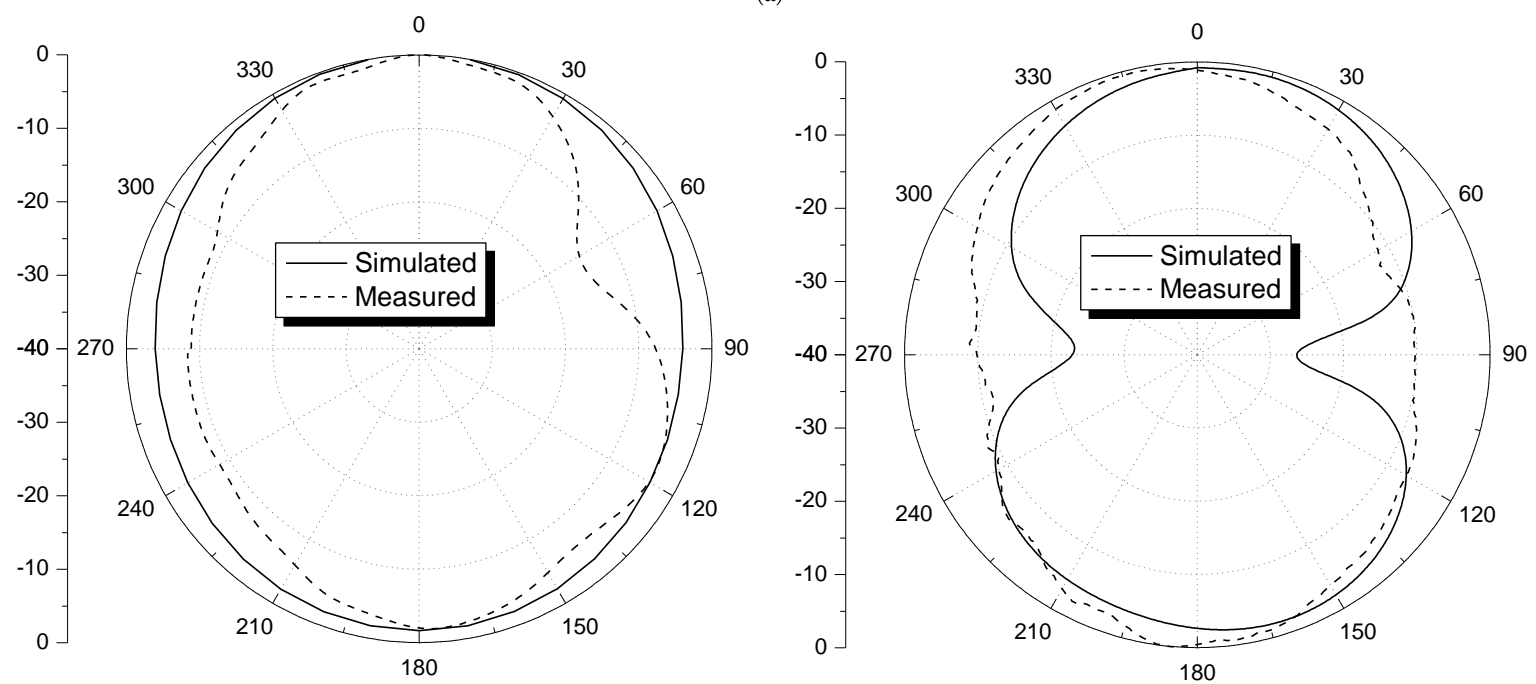

(b)
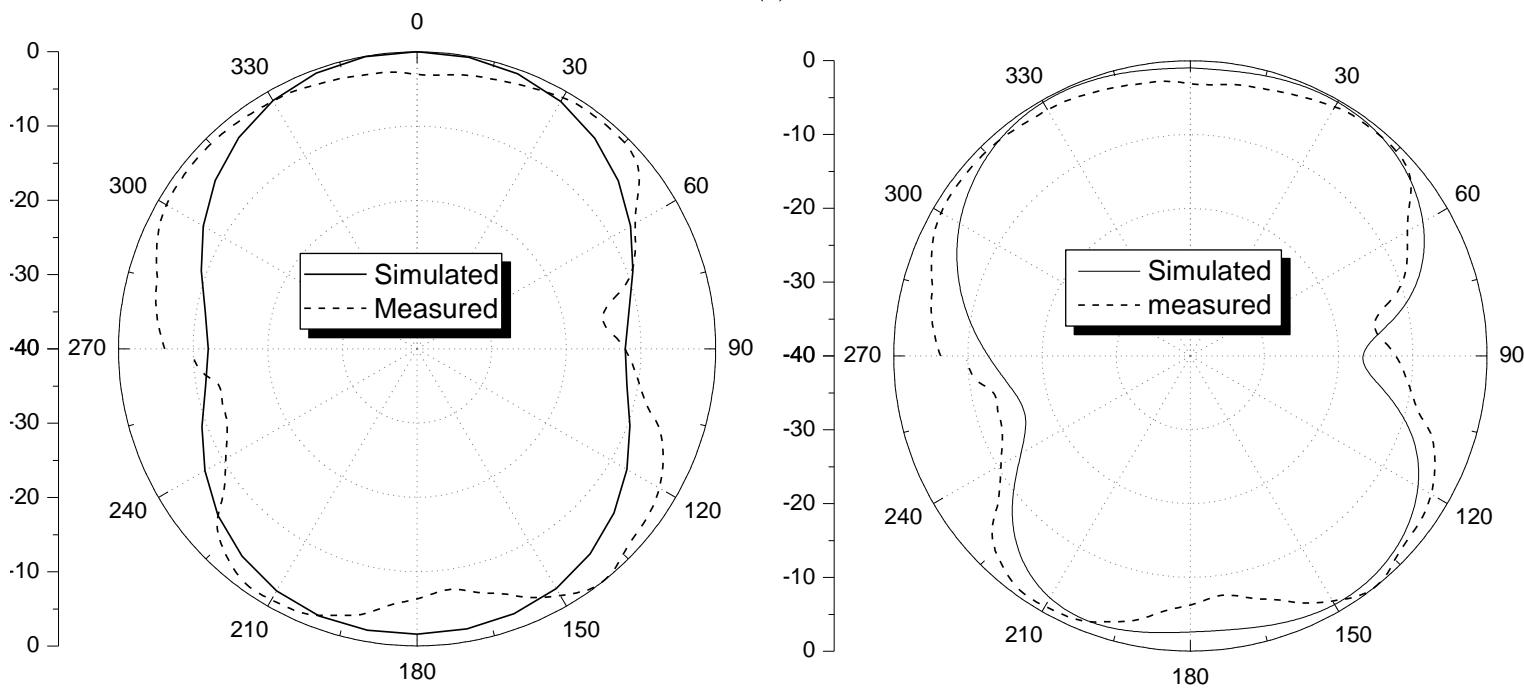

(c)

Fig. 6. Measured and simulated radiation patterns of the single-notched antenna at a) $3.5 \mathrm{GHz}$, b) $4.5 \mathrm{GHz}$ and c) $9 \mathrm{GHz}$ 


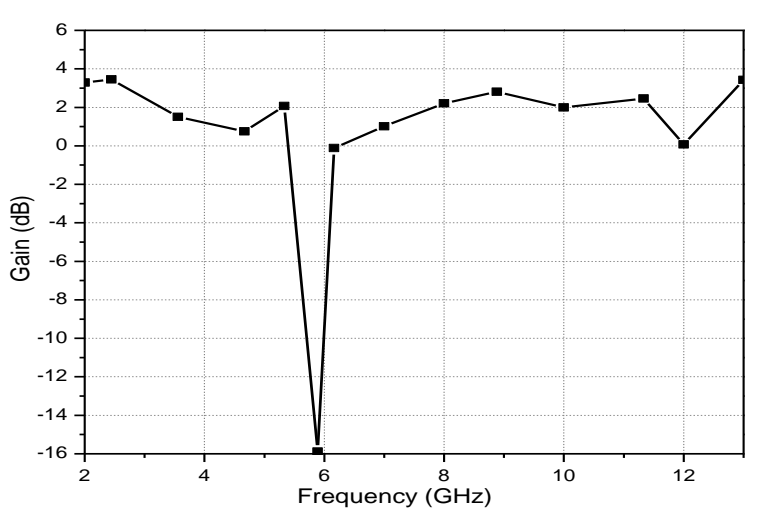

Fig. 7. Simulated Gain of the single-notched antenna.

\section{CONCLUSIONS}

In this paper a clean slot as radiating element and C-shaped slot to the feeding element is introduced. This simple design guarantees radiation pattern stability and easy fabrication. A single band-notched UWB antenna is presented. To reduce the interference between the UWB system and the narrowband WLAN system a microsrip-fed planar UWB antennas with single notched-band at the undesired frequencies has been proposed and discussed. The proposed antenna has the frequency band of $3 \mathrm{GHz}$ to over $10.5 \mathrm{GHz}$ for a VSWR less than 2.0, with a rejection band at 5.8 GHZ. These features make this antenna suitable for UWB communication systems and simplify these systems by rejecting unwanted frequency bands in the antenna level.

\section{REFERENCES}

[1] Wong. FCC, "Revision of part 15 of the commission's rules regarding ultra-wideband transmission systems", Tech. Rep. ETDocket 98153, FCC02-48, Federal Communications Commission, Apr. 2002.

[2] J. Kim, C. S. Cho, and J.W. Lee, " $5.2 \mathrm{GHz}$ notched ultra-wideband antenna using slot-type SRR,” Electron. Lett, vol. 42, no. 6, pp. 315-316, March 2006.

[3] Y. Zhang, W. Hong, C. Yu, Z-Q. Kuai, Y-D Don, and J-Y Zhou, "Planar Ultrawideband Antennas With Multiple Notched Bands Base on Etched Slots on the Patch and/or Split Ring Resonators on the Feed Line," IEEE Trans.
Antennas Propag., vol. 56, no. 9, pp. 3063-3068, September 2008.

[4] Y. W. Jang, Experimental study of a large bandwidth rectangular microstrip-fed circular slot antenna, Microwave Opt Technol Lett 33(2002), 316-318.

[5] Y. F. Liu, K. L. Lau, Q. Xue, and C. H. Chan, Experimental studies of printed wide-slot antenna for wide-band applications, IEEE Antenna Wireless Propagat Lett 3(2004), 273-275.

[6] W.J. Lui, C. H. Cheng, and H. B. Zhu, "Improved frequency notched ultra-wideband slot antenna using square ring resonator", IEEE Trans. Antennas \& Propagation, 55(9), pp. 2445-2450, Sep. 2007.

[7] M. Mehranpour, J. Nourinia, Ch. Ghobadi, and M. Ojaroudi, "Dual Band Notched Square Monopole Antenna for Ultra-Wideband Applications" IEEE Antennas and Wireless Propagation Letters, Vol. 11, pp. 172-175, 2012.

[8] A. Kalteh, G. DadashZadeh, M. Naser, and B. Virdee, "Ultra-wideband circular slot antenna with reconfigurable notch band function" IET Microw. Antennas Propag., vol. 6, Iss. 1, pp. 108-112, 2012.

[9] P. Rakluea, and J. Nakasuwan, "Planar UWB Antenna with Single Band-Notched Characteristic" International Conference on Control, Automation and Systems, Korea, Oct. 2010.

[10] A. Arriola, E. Soliman, S. Brebels, and W. De Raedt, "Single and Dual Band-Notched UWB Antennas with U_shaped Structures” Proceedings of the 39th European Microwave Conference, EuMC2009, pp. 89-92, 2009.

[11] A. Shaalan, and M. Ramadan, "Single and Dual Band-Notched UWB Monopole Antennas with U-Shaped Slot" IEEE Middle East Conference on Antennas and Propagation (MECAP), pp. 1-8, 2010.

[12] R. Zaker, C. Ghobadi, and J Nourinia, "Bandwidth Enhancement of Novel Compact Single and Dual Band-Notched Printed Monopole Antenna with a Pair of L-Shaped Slots" IEEE Transactions on Antennas and Propagation, Vol. 57, No. 12, pp. 3978-3983, Dec. 2009.

[13] B. Ahmadi, and R. Faraji-Dana, "A miniaturized monopole antenna for ultra-wide band applications with band-notch filter" IET Microw. 
Antennas Propag., vol. 3, Iss. 8, pp. 1224-1231, 2009.

[14] A. Mehdipour, A. Parsa, A. Sebak, and C. Trueman, "Miniaturised coplanar waveguide-fed antenna and band-notched design for ultrawideband applications" IET Microw. Antennas Propag., vol. 3, Iss. 6, pp. 974-986, 2009.

[15] W-S. Lee, D-Z. Kim, K-J. Kim and J-W. Yu, "Wideband Planar Monopole Antennas with Dual Band-Notched Characteristics," IEEE Trans. Antennas Propag. vol. 54, no. 6, pp. 2800-2806, June 2006.

[16] A. Djaiz, M.A. Habib, M. Nedil, T.A. Denidni, "Design of UWB filter -antenna with notched band at $5.8 \mathrm{GHz}$,"AP Society International Symposium, APSURSI '09. IEEE, pp:1 - 4, 1-5 June 2009.

[17] A. Djaiz, M.A. Habib, M. Nedil, T.A. Denidni, "Design of Rectangular UWB Slot Antenna Dual-Band Notched at 3.5/5.8 GHz," IEEE Ap-S 2010, Antenna and Propagation Society, International Symposium, Toronto, ON.

[18] HP-ADS, Momentum User's Manuel. Palo Alto, CA: Agilent, Technol., 2006. 


\title{
تصميم وتنفيذ هوائي ذو نطاق ترددي عريض جداً مع وجود ثغرة عند تردد 5.8 جيجا هرتز تمنع عندها اشعاع الموجات
}

\author{
عز الدين جايز 1 ، طريف الشافعي ، مر اد نديل ، محمد ع. حبيب ، طيب ا. دنيدني \\ 1 كلية ينبع الصناعية، ينبع، المملكة العربية السعودية

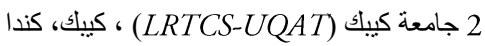 \\ 3 \\ 4
}

الملخص:

تقدم هذه الورقة البحثية هو ائي جديد بوجود فتحة في الثريحة المعدنية اعلي الطبقة العازلة ويتميز هذا الهوائي بالنطاق الترددي العريض جدا مع وجود ثخرة في النطاق الترددي ليس عندها اشعاع للموجات وهذه الثغرة عند تزردد 5.8 جيجاهرتز.

يتم تغذية هذا الهو ائي الجديد من خلال شريعة معدنية متتاهية العرض وتتكون من فتحة مستطيلة وورقة معدنية مستطيلة باستخدام الحث التأثيري بينهما. يسمح هذا التصميم بالحصول على انسب حجم واداء ومو اصفات. وتم الانتهاء من تصميم الهو ائي وتصنيعه واختباره بنجاح. وتم الحصول على نتائج جيدة فيما يتعلق بالاداء في نطاق عدم الاشعاع و الثبات في الاشعاع في باقي النطاق الترددي.

ومن أهم النتائج التي تم الحصول عليها نسبة الفولت في الموجة الثابتة تصل الى 2 في النطاق الترددي من 3.1 الى 10.6 جيجاهرتز وذلك طبقا لمعايير الهيئة الفيدرالية للاتصالات الامريكية وهي ما تمثل عرض للنطاق الترددي يصل الى 115\%. كما تم الوصول الى بعض النتائج المهمة الاخرى تم ايجاز ها في تقرير البحث. 